Michael Bourdeaux makes two noteworthy contributions to public knowledge of the Baptist schism in the present volume. First, he updates the earlier account contained in his Religious Ferment in Russia (1968). Since that time a great number of Baptist protest documents have reached the West, and Bourdeaux makes effective use of them in portraying both the extent of the reform movement and the brutality of the Soviet reaction to it. A smuggled transcript of the trial of Action Group leaders Georgii Vins and Gennadii Kriuchkov is especially revealing. Second, Bourdeaux makes the whole story of the movement available to the general public by presenting it in a deliberately popular style. Such an approach has its costs in the sacrifice of depth and detail, but it is to be welcomed as potentially a most valuable extension of the scholar's service to society.

Unfortunately Bourdeaux's popularization fails to live up to its full potential, for the reason that it is employed so obviously in the service of special pleading. This is a deeply committed book; its bias is proclaimed by everything from the jacket description ("the heroic story of the brave Protestants who are fighting for religious freedom in the Soviet Union") to the concluding announcement of a public appeal on behalf of an organization headed by Bourdeaux which has as one of its aims to provide a sounding board for "Christians living under communism." For many readers the intensity of Bourdeaux's dedication to the Baptists and their cause will diminish his authority. This is regrettable, but it can hardly be avoided when the genuinely shocking facts of the dissidents' lot-facts which speak eloquently for themselves-are embroidered with unnecessarily simplistic assurances of the supreme moral virtue of the Christians and the bloodthirsty villainy of the Communists.

James P. Scanlan

The Ohio State University

\title{
SEASONAL INFLUENCES IN SOVIET INDUSTRY. By Raymond Hut- chings. London, New York, Toronto: Oxford University Press, for the Royal Institute of International Affairs, 1971. xiii, $321 \mathrm{pp} . \$ 13.00$.
}

This is the first full-length study of seasonality in Soviet industry, combined with some comments concerning seasonality in other sectors of the economy. The period covered is from 1924 through 1967, but useful data for subbranches of industry are only available from 1958 on.

Hutchings analyzes the pattern and degree of seasonality of a large number of industrial subbranches, although unfortunately the quarterly data which are available do not fully correspond to the relevant seasons. Having examined long-term trends in seasonal fluctuation, he then compares seasonality in a single republic (Uzbekistan) with that of the Soviet Union as a whole. Here he gets the expected result that seasonality is greater in a geographic subunit of a country than in the country as a whole. Next he proceeds to examine causes of seasonality and of changes in seasonal patterns over time, as well as the interconnections between seasonal patterns in different subbranches. As might be expected, the geography of the Soviet Union and the degree and structure of its industrial development in any year seem to have a much greater effect upon seasonality than does the nature of the planning system.

The author compares Soviet with Canadian seasonality on the ground that Canada is the most comparable country. Using his own index for the degree of 
seasonal fluctuation, he finds that the two countries have much the same degree of seasonal fluctuation; moreover, they seem to have a similar pattern as between quarters of the year. This strengthens your reviewer's impression from Hutchings's study that Soviet planning has had no great independent effect here.

Much of the literature concerning Soviet planning has emphasized the phenomenon of "storming" at the end of a plan period, with a reduction in output at the beginning of the next. This analysis leads to the hypothesis that the fourth quarter should represent the seasonal peak and that the first quarter should be the low. Hutchings's data do not allow us to test this hypothesis, but we can test a weaker form of it. Using 443 years of data for 63 subbranches, only 51 percent of those showing a seasonal increase or decrease in the fourth quarter displayed the predicted increase. More support is available for the hypothesis in the data for the first quarter, where the comparable figure is 61 percent. Thus these data provide very weak support for the storming thesis.

But two other pieces of evidence which Hutchings presents are relevant here. One is that the "typical" Canadian seasonal pattern is the same as the Soviet, although the storming phenomenon would not be predicted to apply nearly as strongly. Second, the same seasonal pattern existed in Soviet industry during 1925-27, even though October-December was then the first instead of the fourth quarter of the planning year. Moreover, the degree of seasonal difference in movement between October-December and January-March was no greater in the one available year of the 1930s than in these earlier years. To sum up, Hutchings's seasonal data provide no support for the storming thesis. This reviewer must confess that he finds this result surprising, but it seems to represent the first time that the storming thesis in Soviet industry has been tested with aggregative data.

Hutchings's study has been carried out competently and quite painstakingly, but the only general result which this reviewer finds interesting is the implied one that the nature of the Soviet Union's economic system has not had a great effect upon seasonality.

\section{David Granick \\ University of Wisconsin, Madison}

\section{ALIENATION AND THE SOVIET ECONOMY: TOWARD A GENERAL THEORY OF MARXIAN ALIENATION, ORGANIZATIONAL PRIN- CIPLES, AND THE SOVIET ECONOMY. By Paul Craig Roberts. Albuquerque: University of New Mexico Press, 1971. xi, 121 pp. $\$ 6.00$.}

In this book Professor Roberts presents us with his answers to two of the "big questions" about the Soviet economy: What is it? Why is it what it is? His answers on both points depart substantially from what he considers to be the standard interpretations. Specifically he contends that the Soviet economy is not centrally planned, but polycentric in its organization and structure, and that its peculiarities are best understood as a direct outcome of the impact on the system of the original aspirations of Marxian socialism.

Chief among these aspirations was the elimination of alienation via the abolition of commodity production. (The author belongs to that school of Marxology which sees alienation not as a passing preoccupation of the young Marx but as a pervasive theme underlying all of his mature work.) As orthodox Marxists, then, Lenin and his comrades could envision their economic tasks in no other terms. In 